\title{
Safety and Efficacy of Galactogogues: Substances that Induce, Maintain and Increase Breast Milk Production
}

\author{
Antonio Alberto Zuppa, Paola Sindico, Claudia Orchi, Chiara Carducci, Valentina Cardiello, \\ Costantino Romagnoli, Piero Catenazzi.
}

Department of Pediatrics, Division of Neonatology, Catholic University of the Sacred Heart, Rome, Italy

Received, February 15, 2010; Revised, April 25, 2020; Accepted, May 10, 2010, Published, May 11, 2010

\begin{abstract}
Poor breast milk production is the most frequent cause of breast-feeding failure. This quite common clinical problem is frequently addressed by physicians by prescribing pharmaceuticals and other products to enhance milk production, namely galactagogues. The use of galactagogues should be restricted to patients with a no treatable cause of reduced breast milk production. One of the most frequent indication for the use of galactagogues is the diminution of milk production in mothers using indirect lactation, particularly in the case of preterm birth. The aim of this review is to analyze and review the literature on the most widely used pharmaceuticals that are used as galactagogues (metoclopramide, domperidone, chlorpromazine, sulpiride, oxytocin, growth hormone, thyrotrophin releasing hormone, medroxyprogesterone). We will also analyze the literature supporting the use of herbs and other products (fenugreek, galega and milk thistle). Each product has been evaluated based on its mechanism of action, transfer properties to maternal milk, effectiveness and potential side effects for mother and infant, suggested doses for galactagogic effect, and recommendations for breastfeeding.
\end{abstract}

\section{INTRODUCTION}

Maternal milk is currently considered the optimal feeding for all babies. Breast-feeding is associated with better nutritional and non-nutritional outcomes compared with formula feeding even in case of preterm birth.(1,2,3,4). Poor breast milk production is the most frequent cause of breastfeeding failure (5). A reduced breast milk production can occur in many circumstances, such as preterm birth, illness of the mother or the child, mother-baby separation, re-lactation after a prolonged suspension and indirect lactation (breast pump or manual milk expression). Anxiety, fatigue, and emotional stress are also powerful inhibitors of lactation. Educational programs should be offered to all breastfeed mothers to address problems such as inadequate frequency and duration of breastfeeding, incorrect breast attachment, inadequate breast emptying during manual or mechanical milk expression.

Milk production can be increased in several other ways, such as psychological support and relaxation techniques (for example using books or audio/video supports). Nevertheless, many mothers ask quite often their physician for medications or other products to increase their breast milk production (5). The use of galactagogues should be limited to those situations in which reduced milk production from treatable causes has been excluded, and to "surrogate" and adoptive mothers who want breastfeeding.

Prolactin (PRL) is a peptide hormone primarily synthesized and secreted by adenohypophysis. PRL is secreted into blood stream in response to the suckling stimulus on the maternal nipple. Most of the existing galactagogues act by increasing the production and release of PRL by the anterior pituitary gland. The mechanisms of action of these drugs range from the direct stimulation of the adenohypophysis to the suppression of the hypothalamic secretion of PRL inhibitory factor (PIF) and stimulation of the hypothalamus to secrete PRL releasing hormone. In addition, as dopamine is a physiologic inhibitor of PRL release, some galactagogues act either by blocking hypothalamic dopaminergic receptors (e.g metoclopramide and domperidone) or by inhibiting dopamine-producing neurons (6).

The mechanism of breast milk production presented above provides only a simplified framework to understand the mechanisms of action of the many different galactagogues. Some authors suggest more complex relationship between blood PRL concentrations and milk synthesis.

Corresponding Author: Antonio Alberto Zuppa, Department of Pediatrics, Division of Neonatology, Catholic University of the Sacred Hearth, Largo Agostino Gemelli 8, 00168 Rome Italy, E-Mail address: zuppaaa@rm.unicatt.it 
Cox et al (7) found no direct relationship between plasma concentration of prolactin and rate of milk synthesis in a group of eleven nursing women.

Nevertheless the authors do not preclude the involvement of PRL in milk production but suggest a complex interplay of autocrine inhibitors and endocrine effectors. Other evidences suggest a relationship between maternal parity and basal PRL levels (8) based on a study of a group of 21 nursing women, either primiparous or multiparous, on the $2^{\text {nd }}, 3^{\text {rd }}$ and $4^{\text {th }}$ day of the puerperium. Despite an increased level of breast milk production in multiparous women, they showed lower levels of serum PRL compared with primiparous women. The authors explain this seeming paradox relationship by an increased number of occupied PRL receptors in the mammary glands.

For any medications or other substances to be used as galactogogues, the side effects on both the mother and infant must be fully evaluated $(4,9,10)$. The aim of this review is to analyze the literature on the most widely used galactagogues. Each drug will be evaluated for its mechanism of action, transfer properties to maternal milk, suggested dosages, effectiveness and potential side effects for mother and infant.

\section{METHODS}

In the Pubmed database, we matched the name of drug/natural substance with the terms "milk", lactation", "breastfeeding" and "galactagogues" respectively. Searches were limited to English and Italian language articles and to human studies. Considering the paucity of literature on the subject, we decided to include, in addition to original research articles, various type reports such as reviews and cases report.

\section{ANTIEMETICS}

\section{Metoclopramide}

Mechanism of Action: Metoclopramide antagonizes the release of dopamine in the central nervous system (CNS), thereby, increases PRL levels $(4,10-23)$.

Clinical data: With one early exception (24) reports suggest positive effects of various dosing regimens of metoclopramide on milk production which generally is accompanied by an increase in PRl $(10,14,16,18,21)$ in mothers as well as TSH, and FT4 in both mothers and infants (18). Ertl et al (14) observed that the increased milk production by metoclopramide was also accompanied by an increased milk sodium concentration and the infants' serum PRL levels.

The effectiveness of metoclopramide has been evaluated even in the case of preterm births has been studied by Ehrenkranz et al (4) who treated 23 mothers of preterm infants (GA $30.4 \pm$ 0.7 weeks) 32 days after delivery. They noticed increased plasma PRL levels and milk production after 7 days of therapy. A more recent randomized conducted a double-blind study in mothers of preterm infants (GA 23-34 weeks) in which the therapy commenced $96 \mathrm{~h}$ post-partum, however, no differences in either milk production or the duration of breastfeeding has been observed between control and treated groups (25).

In combination with oxytocin nasal spray and breast squeezing, metoclopramide has been found effective in inducing lactation (13). Metoclopramide $\left(10 \mathrm{mg}\right.$ t.i.d. from the $28^{\text {th }}$ week of gestation to one week before delivery) has also been reported to result in successful lactation in a post-hysterectomy patient with an infant from a surrogate pregnancy (11).

Transfer to mother's milk: Metoclopramide is transferred to breast milk where it is concentrated with a milk-to-plasma $(\mathrm{M} / \mathrm{P})$ ratio of $1.8-1.9$ $(16,19,24)$. Similar to other alkaline medications, metoclopramide concentration is greater in milk than in plasma due to a greater extent of ionization in mature milk with $(\mathrm{pH}, 6.8-7.0)$. However, assuming that the total quantity of daily milk ingested by the average infant is 1 liter, the author calculated that the metoclopramide taken in by the suckling was equal to $45 \mu \mathrm{g} / \mathrm{kg} /$ day that is so low that is unlikely to result in any effect (19). Other studies confirm a lower that pharmacologically effective concentration in milk $(17,26)$. The milk concentration in colostrums ( $\mathrm{pH}$, milk>plasma, newly initiated milk) is expected to be even less than what has been reported for mature milk

Side effects for infant and for mother: There have been only two reports of mild and transient intestinal discomfort in infants breastfed by mothers undergoing metoclopramide therapy (30 and $45 \mathrm{mg}$ /day) $(20,21)$. Other authors have reported the absence of side effects in newborns $(4,15,17,21,24,26)$. Among maternal side effects, Kauppila et al (20) reported tiredness, headache, anxiety, and intestinal disorders. Ehrenkranz et al (4) described nervousness, sleepiness, and fatigue in $10 \%$ of treated mothers, and insomnia, 
headache, intestinal disorders and extrapyramidal manifestation in $1 \%$.

Recommended dosages for galactogogic effect: 10-15 mg per t.i.d., po for 1-4 weeks.
Recommendation for breastfeeding: Lewis et al advised against the use of metoclopramide during breast feeding on the basis of potential risks for the infant due to transfer of the medication in maternal milk (35).

Table 1. Summary of reports on the use of metoclopramide as galactogogues

\begin{tabular}{|c|c|c|c|c|c|c|c|}
\hline References & Methods & $\begin{array}{l}\text { No subjects } \\
\text { (mothers) }\end{array}$ & Dosage & Main outcome & $\begin{array}{l}\text { Maternal } \\
\text { Side effects }\end{array}$ & $\begin{array}{l}\text { Transfer to } \\
\text { mother's } \\
\text { milk }\end{array}$ & $\begin{array}{l}\text { Infant side } \\
\text { effects }\end{array}$ \\
\hline 16 & $\begin{array}{l}\text { Case- } \\
\text { control } \\
\text { study }\end{array}$ & 21 & $20 \mathrm{mg} /$ day & $\begin{array}{l}\text { Increase in PRL levels } \\
\text { and milk production. }\end{array}$ & & $\begin{array}{l}\text { Lower than } \\
\text { the accepted } \\
\text { therapeutic } \\
\text { dose }\end{array}$ & None \\
\hline 24 & $\begin{array}{l}\text { Double- } \\
\text { blind RCT }\end{array}$ & $\begin{array}{l}20 \text { had delivered } \\
\text { by cesarean } \\
\text { section }\end{array}$ & $\begin{array}{l}10 \mathrm{mg} \text { three times } \\
\text { a day, for } 7 \text { days } \\
\text { after delivery }\end{array}$ & $\begin{array}{l}\text { The therapy did not } \\
\text { appear to be more } \\
\text { effective }\end{array}$ & & & None \\
\hline 21 & & 17 & $\begin{array}{l}10 \text { mg, three } \\
\text { times a day for } 3 \\
\text { weeks, } \\
\text { discontinued for } \\
\text { one week, and } \\
\text { then resumed for } \\
\text { an additional two } \\
\text { weeks }\end{array}$ & $\begin{array}{l}\text { Increase in PRL level. } \\
\text { Levels of TSH, T3, and } \\
\text { T4 were unaffected by } \\
\text { the treatment }\end{array}$ & $\begin{array}{l}\text { Tiredness, } \\
\text { headache, } \\
\text { anxiety, and } \\
\text { intestinal } \\
\text { disorders }\end{array}$ & $\begin{array}{l}\text { Lower than } \\
\text { the accepted } \\
\text { therapeutic } \\
\text { dose }\end{array}$ & $\begin{array}{l}\text { Mild and } \\
\text { transient } \\
\text { intestinal } \\
\text { discomfort in } \\
\text { infants } \\
\text { breastfed }\end{array}$ \\
\hline 10 & $\begin{array}{l}\text { Double- } \\
\text { blind } \\
\text { controlled } \\
\text { clinical trial }\end{array}$ & 13 Primiparous & $\begin{array}{l}10 \mathrm{mg} \text {, three } \\
\text { times a day } \\
\text { beginning on the } \\
\text { first postnatal day } \\
\text { and continuing } \\
\text { for } 8 \text { days }\end{array}$ & $\begin{array}{l}\text { Milk production was } \\
\text { more than } 50 \% \text { higher } \\
\text { than in the placebo } \\
\text { group, a more rapid } \\
\text { transition from } \\
\text { colostrum to mature } \\
\text { milk }\end{array}$ & & & None \\
\hline 18 & $\begin{array}{l}\text { Double- } \\
\text { blind RCT }\end{array}$ & 25 & $\begin{array}{l}10 \mathrm{mg} \text {, twice a } \\
\text { day for } 3 \text { weeks }\end{array}$ & $\begin{array}{l}\text { PRL increase and TSH } \\
\text { and FT4 in both mothers } \\
\text { and infants, and PRL } \\
\text { levels in infants, } \\
\text { remained unchanged }\end{array}$ & & & \\
\hline 4 & & $\begin{array}{l}23 \text { mothers of } \\
\text { preterm infants }\end{array}$ & $\begin{array}{l}30 \mathrm{mg} \text { three times } \\
\text { a day started } 32 \\
\text { days after } \\
\text { delivery }\end{array}$ & $\begin{array}{l}\text { Increase in plasma PRL } \\
\text { levels and an increase in } \\
\text { milk production, after } 7 \\
\text { days of therapy }\end{array}$ & $\begin{array}{l}\text { Nervousnes, } \\
\text { sleepiness, and } \\
\text { fatigue in } 10 \% \text { of } \\
\text { treated mothers, } \\
\text { and insomnia, } \\
\text { headache, } \\
\text { intestinal } \\
\text { disorders, and } \\
\text { extrapyramidal } \\
\text { manifestation in } \\
1 \%\end{array}$ & & None \\
\hline
\end{tabular}

\begin{tabular}{|c|c|c|c|c|}
\hline 14 & $\begin{array}{l}\text { Case- } \\
\text { control } \\
\text { study }\end{array}$ & 11 & $\begin{array}{l}30 \mathrm{mg} / \text { day for } 5 \\
\text { day }\end{array}$ & $\begin{array}{l}\text { Increase of milk } \\
\text { production.PRL levels, } \\
\text { milk sodium } \\
\text { concentration, and the } \\
\text { serum PRL of the infants } \\
\text { were similar in the two } \\
\text { groups. }\end{array}$ \\
\hline 13 & Case-report & Adoptive mother & $\begin{array}{l}\text { Use of bilateral } \\
\text { pumping, } \\
\text { metoclopramid, } \\
\text { syntocinon nasal } \\
\text { spray }\end{array}$ & $\begin{array}{l}\text { Lactogenesis was } \\
\text { initiated within } 10 \text { days } \\
\text { of the adoption }\end{array}$ \\
\hline 11 & Case-report & $\begin{array}{l}\text { Post- } \\
\text { hysterectomy } \\
\text { patient with a } \\
\text { baby from a } \\
\text { surrogate } \\
\text { pregnancy }\end{array}$ & $\begin{array}{l}10 \mathrm{mg} \text { three times } \\
\text { a day, from the } \\
28^{\text {th }} \text { week of } \\
\text { gestation to one } \\
\text { week before } \\
\text { delivery. }\end{array}$ & $\begin{array}{l}\text { Lactation was successful } \\
\text { induced }\end{array}$ \\
\hline 25 & $\begin{array}{l}\text { Double- } \\
\text { blind RCT }\end{array}$ & $\begin{array}{l}57 \text { mothers of } \\
\text { preterm infants }\end{array}$ & $\begin{array}{l}10 \mathrm{mg}, 3 \text { times a } \\
\text { day for } 10 \text { days, } \\
\text { starting within } 96 \\
\text { hours after } \\
\text { delivery }\end{array}$ & $\begin{array}{l}\text { No differences in either } \\
\text { milk production or the } \\
\text { duration of } \\
\text { breastfeeding was seen } \\
\text { between the two groups }\end{array}$ \\
\hline
\end{tabular}


In 2001, AAP described metoclopramide as a medication that its effect on infants was controversial (36). Some authors, however, have considered metoclopramide compatible with breastfeeding as long as its dose does not exceed $45 \mathrm{mg} /$ day $(37,38)$. Table 1 summarizes the main works cited above.

\section{Domperidone}

Domperidone is not currently available in the United States. Due to reports of cardiac arrythmia and sudden death in cancer patients treated with intravenous domperidone indicated as an antiemetic $(33,46-48)$, the US FDA banned the use of the drug in July 2004 even as a lactation enhancer $(28,42)$. In Canada, Domperidone is approved for the treatment of upper gastric motility. However its use as a breast milk enhancer is an "off label" indication.

Mechanism of Action: It is an antiemetic agent that acts as a peripheral dopamine antagonist. It rises PRL levels, leading to an increase in milk production $(31,32,39-41)$.

Clinical Data: In a double-blind RCT on 32 mothers of term infants with poor lactation who received either domperidone (10 $\mathrm{mg}$ t.i.d.) or placebo significant increase in daily milk production was observed in the treated mothers (41).

Da Silva et al conducted a double-blind RCT on mothers of preterm infants, dispensing, for 7 days, domperidone (10 mg, 3 t.i.d.) to 11 subjects and a placebo to the remaining 9. The daily volume of milk produced by each mother was recorded. The serum levels of domperidone and PRL were obtained from three blood samples, one drawn before the first dose, and the others on days 5 and 10. In comparison to basal values, milk production during the first 7 days increased by $44.5 \%$ in treated mothers, and by $16.6 \%$ in controls. However, basal levels of milk production were higher in the treated group than in the placebo group (112.6 \pm 128.7 vs. $48.2 \pm$ $63.3 \mathrm{ml}$ ). By day 5, serum levels of PRL were significantly higher in the treated women (40).

In 2003 a randomized clinical trial on the effect of domperidone on milk composition, (9) was interrupted when FDA halted the use of this drug in USA (42).

Transfer to maternal milk: Domperidone is only $13-17 \%$ bioavailable due to a significant hepatic and gut first-pass metabolism (39). It is transferred to maternal milk in slight quantities due to its high molecular weight and its $90 \%$ binding to plasma proteins (30). After administering $10 \mathrm{mg}$ of domperidone 3 times a day for 4 days Hofmeyer et al found a concentration in serum and in milk, of 10 and 2.6 $\mathrm{ng} / \mathrm{ml}$ respectively (31). In another study the same authors found that the concentrations in serum and in milk to be 8.0 and $0.24 \mathrm{ng} / \mathrm{ml}$, respectively, with an $\mathrm{M} / \mathrm{P}$ ratio of $0.03,2 \mathrm{~h}$ after the administration of a single dose of $20 \mathrm{mg}$ of domperidone. At $4 \mathrm{~h}$ post-dose the $\mathrm{M} / \mathrm{P}$ ratio was 1.1 (32). After 5 days of treatment with domperidone (10 mg 3 times a day) Da Silva et al found an average serum and milk concentrations of 6.6 and $1.2 \mathrm{ng} / \mathrm{ml}$ respectively, with an $\mathrm{M} / \mathrm{P}$ ratio of 0.18 . With an average daily ingestion of $150 \mathrm{ml} / \mathrm{kg}$ of milk, the authors calculated a drug intake of less than $0.2 \mu \mathrm{g} / \mathrm{kg}$ for the infant (40).

Side effects for mother and for infant: No of side effects has been reported in the infants whose mothers take domperidone $(31,32,40,41)$. Mothers with cardiac diseases should avoid using this drug due to potential arrythmia (43). Domperidone is less permeable through the blood/brain barrier than metoclopramide as it is less soluble, has a higher molecular weight and binds to plasma proteins more strongly $(31,39,41,44)$. This chemical properties reduce adverse extrapyramidal effects rendering domperidone a good alternative to metoclopramide as a galactagogues. Fewer cases of dystonia have been reported with this drug as compared with metoclopramide (45).

The most common side effects for mothers include oral mucosal dryness, skin eruption, itch, headache and gastrointestinal disorders (45).

Recommended dosage for galactagogic effect: $10 \mathrm{mg}$ po, 3 times a day for $1-2$ weeks $(31,32,40)$. However, additional investigations are necessary to determine the minimum effective dose and the needed duration of therapy (43).

Recommendations for breastfeeding: Currently few data are available on the use of domperidone as a galactogogue. In 2001, the AAP included domperidone among the drugs compatible with breastfeeding (35). 
Table 2. Summary of reports on the use of domperidone as galactogogues

\begin{tabular}{|c|c|c|c|c|c|c|c|}
\hline References & Methods & $\begin{array}{l}\text { No } \\
\text { subjects } \\
\text { (mothers) }\end{array}$ & Dosage & $\begin{array}{l}\text { Main } \\
\text { outcome }\end{array}$ & $\begin{array}{l}\text { Maternal } \\
\text { Side } \\
\text { effects }\end{array}$ & $\begin{array}{l}\text { Transfer to } \\
\text { mother's milk }\end{array}$ & $\begin{array}{l}\text { Infant side } \\
\text { effects }\end{array}$ \\
\hline 41 & $\begin{array}{l}\text { Double- } \\
\text { blind RCT }\end{array}$ & $\begin{array}{l}32 \text { of term } \\
\text { infants }\end{array}$ & $10 \mathrm{mg}, 3$ times a day & $\begin{array}{l}\text { Significant } \\
\text { increase in daily } \\
\text { milk production }\end{array}$ & & & Absence \\
\hline 40 & $\begin{array}{l}\text { Double- } \\
\text { blind RCT }\end{array}$ & $\begin{array}{l}20 \text { of preterm } \\
\text { infants }\end{array}$ & $\begin{array}{l}7 \text { days, } 10 \mathrm{mg}, 3 \\
\text { times a day }\end{array}$ & $\begin{array}{l}\text { Increase of basal } \\
\text { levels of milk } \\
\text { production, } \\
\text { increase of serum } \\
\text { levels of PRL }\end{array}$ & & $\begin{array}{l}\text { Average serum and } \\
\text { milk concentrations to } \\
\text { be } 6.6 \text { and } 1.2 \mathrm{ng} / \mathrm{ml} \\
\text { respectively, with an } \\
\text { average daily ingestion } \\
\text { of } 150 \mathrm{ml} / \mathrm{kg} \text { of milk, } \\
\text { the author calculated a } \\
\text { drug intake of less than } \\
0.2 \mu \mathrm{g} / \mathrm{kg}\end{array}$ & Absence \\
\hline
\end{tabular}

\section{ANTIPSYCHOTIC}

\section{Chlorpromazine}

Mechanism of action: It increases PRL levels by antagonizing the dopaminergic hypothalamic receptors (49).

Clinical data: Weichert et al (49) evaluated improvement in milk production in four patients with poor lactation who were given chlorpromazine ( $25 \mathrm{mg}, 3$ times a day for 7 days). They also monitored the weight of the infant weekly. There was a response in term of increased breast fullness and weight gain.

Transfer to maternal milk: Chlorpromazine is passed to maternal milk in very low quantities (36). Peak concentration in the milk of $0.29 \mu \mathrm{g} / \mathrm{ml}$ after 2 hours following the administration of an oral dose of $1200 \mathrm{mg}$ of chlorpromazine with an $\mathrm{M} / \mathrm{P}$ ratio less than 0.50 has been reported (5). Chlorpromazine was not measurable in the milk after a single oral dose of $600 \mathrm{mg}(50)$.

Wiles et al (51) measured chlorpromazine and the levels of some of its metabolites in the milk and plasma of 4 mothers taking the medication during the postpartum period (the dosage was not documented). Chlorpromazine concentrations in the milk and plasma increased during this period, respectively, from 7 to $98 \mathrm{ng} / \mathrm{ml}$ and from 16 to $52 \mathrm{ng} / \mathrm{ml}$.

Yoshida et al (52) analyzed, over a period of 30 months, 20 breastfeeding mothers who were under therapy with neuroleptic drugs, including chlorpromazine, comparing them with a group of 18 mothers whose infants were fed artificially. Infants ingested up to $3 \%$ of the maternal daily dose per kg body weight and small amounts of the drugs were detected in infants plasma and urine.
Side effects for infant and for mother: Little is known about the pharmacokinetics of neuroleptic drugs in breastfeeding mothers and their infants or about their side effects (52).

According to the AAP, all neurotropic drugs potentially cause short and long-term changes in the development of the CNS, as they concentrate in the brain. Side effects in infants include lethargy, sleepiness, and reduced behavioral performance $(36,52)$. Wiles et al (51) reported sleepiness in an infant breastfed by a woman with high levels of chlorpromazine in her milk (92 $\mathrm{ng} / \mathrm{ml}$ ). In a recent systematic review, Gentile et al argued that it is not possible to reach clear conclusions about the risk-benefit ratio of the main antipsychotic drugs during lactation (53). Some authors advise against the use of these drugs because of the risk to mothers of extrapyramidal symptoms and weight increase (44).

Recommended dosage for galactogogic effect: $25 \mathrm{mg}$ po, 3 times a day for 1 week (49).

Recommendation for breastfeeding: In 2001, the AAP concluded that chlorpromazine can cause acute and chronic alterations on the development of the CNS. They placed chlorpromazine in the group of drugs for which the effect on nursing infants is unknown but may be of concern (36). Briggs et al advised infant monitoring for possible onset of sedation (37).

\section{SULPIRIDE}

Sulpiride, a substituted benzamide, is an antipsychotic drug used in the treatment of psychosis including schizophrenia and depression. It is commonly used in Europe and Japan but not in the US and Canada. 
Table 3. Summary of reports on the use of chlorpromazine as galactogogues

\begin{tabular}{|c|c|c|c|c|c|c|c|}
\hline References & Methods & $\begin{array}{l}\text { No } \\
\text { subjects } \\
\text { (mothers) }\end{array}$ & Dosage & $\begin{array}{l}\text { Main } \\
\text { outcome }\end{array}$ & $\begin{array}{l}\text { Maternal } \\
\text { Side } \\
\text { effects }\end{array}$ & $\begin{array}{l}\text { Transfer to } \\
\text { mother's milk }\end{array}$ & $\begin{array}{l}\text { Infant } \\
\text { effects }\end{array}$ \\
\hline 50 & & & $1200 \mathrm{mg}$ oral dose & & & $\begin{array}{l}\text { A concentration peak in } \\
\text { the milk of } 0.29 \mu \mathrm{g} / \mathrm{ml} \\
\text { after } 2 \text { hours, with an } \\
\mathrm{M} / \mathrm{P} \text { ratio less than } 0.50\end{array}$ & \\
\hline 51 & & 4 & & & & $\begin{array}{l}\text { Increase in the milk and } \\
\text { plasma, respectively, } \\
\text { from } 7 \text { to } 98 \mathrm{ng} / \mathrm{ml} \text { and } \\
\text { from } 16 \text { to } 52 \mathrm{ng} / \mathrm{ml}\end{array}$ & Sleepiness \\
\hline 49 & & 4 & $\begin{array}{l}25 \mathrm{mg}, 3 \text { times a } \\
\text { day for } 7 \text { days }\end{array}$ & $\begin{array}{l}\text { Increase of breast } \\
\text { fullness, and } \\
\text { appropriate } \\
\text { weight gain }\end{array}$ & & & \\
\hline 52 & $\begin{array}{l}\text { Case-control } \\
\text { study }\end{array}$ & 38 & & & & $\begin{array}{l}\text { Infants ingested up to } \\
3 \% \text { of the maternal } \\
\text { daily dose per kg body } \\
\text { weight and small } \\
\text { amounts of the drugs } \\
\text { were detected in } \\
\text { infants' plasma and } \\
\text { urine }\end{array}$ & $\begin{array}{l}\text { Lethargy, } \\
\text { sleepiness, and } \\
\text { reduced behavioral } \\
\text { performance }\end{array}$ \\
\hline
\end{tabular}

Mechanism of action: Sulpiride stimulates hypothalamus to secrete PRL-releasing hormone $(27,54-56)$.

Clinical data: Aono et al (54) randomized 130 primiparous mothers into two groups: 66 received $50 \mathrm{mg}$ of sulpiride twice a day for the first 7 days after delivery, and 64 received a placebo. The average total volume of milk produced in the first 5 days after childbirth was significantly higher in the treated group compared to the control group $(1211 \pm 65$ vs. $916.0 \pm 66 \mathrm{~mL})$. The serum PRL levels, measured daily, were higher in the sulpiride group compared to the control group. Ylikorkala et al (56) conducted a double blind RCT, administering sulpiride $(50 \mathrm{mg}, 3$ times a day for 4 weeks) to 14 hypogalactic mothers, and a placebo to another 12 as controls. In the sulpiride group the serum PRL concentration increased from $49.0 \pm 3.6$ to $402.1 \pm 43.2 \mu \mathrm{g} / \mathrm{l}$ in two weeks, while in the placebo group it diminished from $84.7 \pm 24.0$ to $47.8 \pm 8.6 \mu \mathrm{g} / \mathrm{l}$. From day 5 of treatment, a significant increase in milk production was seen in the treated group (by an average of 212-265 ml). Infants of mothers who took sulpiride had a weight increase greater that those infants whose mothers received a placebo $(1081 \pm 111$ vs. $795 \pm 35 \mathrm{~g} ; p<0.05)$. Polatti et al (57) confirmed the above results. In another study Aono et al (58) evaluated 42 primiparous and 54 multiparous mothers whose milk production was lower than $50 \mathrm{ml}$ in the first three days after delivery by administering either $100 \mathrm{mg}$ sulpiride or placebo for 4 days from the $3^{\text {th }}$ postpartum day. For primiparous mothers, the mean milk volume produced from the $3^{\text {th }}$ to $5^{\text {th }}$ postpartum days was $662 \pm 64$ and $441 \pm 51 \mathrm{ml}$ in the sulpiride group and in the placebo group $(p<$ 0.01 ), respectively. Among the multiparous mothers group there was no evidence of any significant difference in the quantity of milk produced. One month after delivery, $55 \%$ of the treated primiparous mothers were fully breastfeeding in comparison with $30 \%$ of the placebo group. There were no significant difference in breastfeeding among the multiparous mothers.

Ylikorkala et al (59) analyzed 36 women with insufficient milk production in the first four months after delivery; 24 treated with sulpiride (50 mg three times a day for 2 weeks) and 12 with a placebo. Oxytocin $(100,300$, or 400 UI po) or placebo was added before each suck on days 6 and 14 and on days 7 and 13 respectively. The concentration of PRL in the maternal serum was higher in the treated group after one week (380 \pm 43 vs. $23 \pm 7 \mathrm{ng} / \mathrm{ml})$ and after two weeks of treatment $(381 \pm 38$ vs. $34 \pm 10 \mathrm{ng} / \mathrm{ml})(p<0.01)$. The daily production of milk was greater in the treated group in both the first (628 \pm 51 vs. $440 \pm$ $68 \mathrm{ml})$ and the second $(684 \pm 67$ vs. $423 \pm 60 \mathrm{ml})$ week of treatment $(p<0.05)$.

Transfer to maternal milk: Sulpiride is transferred to maternal milk (55). After a maternal dose of $100 \mathrm{mg}$ of sulpiride a concentration in the milk of $1 \mu \mathrm{g} / \mathrm{L}$ has been reported (56).

Side effects for infant and for mother: No side effects for infants have been reported. Three women taking sulpiride reported headache and fatigue (56). 
Table 4. Summary of reports on the use of sulpiride as galactogogues

\begin{tabular}{|c|c|c|c|c|c|c|c|}
\hline References & Methods & $\begin{array}{l}\text { No subjects } \\
\text { (mothers) }\end{array}$ & Dosage & Main outcome & $\begin{array}{l}\text { Maternal } \\
\text { Side effects }\end{array}$ & $\begin{array}{l}\text { Transfer to } \\
\text { mother's milk }\end{array}$ & $\begin{array}{l}\text { Infant } \\
\text { side } \\
\text { effects }\end{array}$ \\
\hline 54 & $\mathrm{RCT}$ & 130 & $\begin{array}{l}50 \mathrm{mg} \text { twice a day } \\
\text { for the first } 7 \text { days } \\
\text { after delivery }\end{array}$ & $\begin{array}{lr}\text { Incresase of } & \text { milk } \\
\text { production, increase } & \text { of } \\
\text { PRL levels } & \\
\end{array}$ & & & \\
\hline 56 & $\begin{array}{l}\text { Double- } \\
\text { blind RCT }\end{array}$ & 26 & $\begin{array}{l}50 \mathrm{mg}, 3 \text { times a } \\
\text { day for } 4 \text { weeks }\end{array}$ & $\begin{array}{l}\text { Increase of PRL } \\
\text { concentration, increase in } \\
\text { milk production. } \\
\text { Infants'weight increase } \\
\text { greater }\end{array}$ & $\begin{array}{l}\text { Three women } \\
\text { reported } \\
\text { headache and } \\
\text { fatigue }\end{array}$ & $\begin{array}{l}\text { Concentration in the } \\
\text { milk of } 1 \mu \mathrm{g} / \mathrm{l}\end{array}$ & Absence \\
\hline 57 & $\begin{array}{l}\text { Double- } \\
\text { blind study }\end{array}$ & 60 multiparous & $\begin{array}{l}50 \mathrm{mg} \text { twice a day } \\
\text { during the first } 5 \\
\text { days after delivery }\end{array}$ & $\begin{array}{l}\text { Increase of milk quantity } \\
\text { in the first } 5 \text { days and } \\
\text { serum levels of PRL }\end{array}$ & & & \\
\hline 58 & $\begin{array}{l}\text { Double- } \\
\text { blind RCT }\end{array}$ & $\begin{array}{lr}42 & \text { primiparous } \\
\text { and } & 54 \\
\text { multiparous }\end{array}$ & $\begin{array}{l}100 \mathrm{mg} \text { for } 4 \text { days } \\
\text { from the } 3^{\text {th }} \\
\text { postpartum day }\end{array}$ & $\begin{array}{l}\text { Significant increase of } \\
\text { milk production in } \\
\text { primiparous. } \\
\text { No significant difference } \\
\text { in breastfeeding in the } \\
\text { multiparous }\end{array}$ & & & \\
\hline 59 & & 36 & $\begin{array}{l}50 \mathrm{mg} \text { three times } \\
\text { a day for } 2 \text { weeks } \\
\text { Oxytocin }(100,300 \text {, } \\
\text { or } 400 \text { UI po) or } \\
\text { placebo was added } \\
\text { before each suck } \\
\text { on days } 6 \text { and } 14 \\
\text { and on days } 7 \text { and } \\
13 \text { respectively }\end{array}$ & $\begin{array}{l}\text { Increase of the } \\
\text { concentration and the } \\
\text { increase of daily milk } \\
\text { production of PRL in the } \\
\text { maternal serum }\end{array}$ & & & \\
\hline
\end{tabular}

Recommended dosage for galactogogic effect: $50 \mathrm{mg}$ po, 2-3 times a day for $1-4$ weeks $(27,54-$ $57,59)$.

Recommendation for breastfeeding: It should be assumed that all neurotropic drugs carry the risk of short and long term-alterations on the development of CNS (36). Some authors have advised against the use of sulpiride due to the risk to mothers of extrapyramidal symptoms, acute dystonic reactions, and increase in weight secondary to endocrine dysfunction (36). Antipsychotic drugs should be avoided in preterm infants or in infants with renal, hepatic, cardiac, or neurologic pathologies (60).

\section{HORMONES}

\section{Oxytocin}

Mechanism of action: Oxytocin causes contraction of the myoepithelial cells that surround the alveoli and milk ducts causing the milk ejection (61).

Clinical data: The effect of oxytocin on increasing milk production was studied by Ruis et al in 1981 in a double-blind RCT (62) on mothers of infants with GA $<38$ weeks. Oxytocin nasal spray $(40 \mathrm{U} / \mathrm{ml})$ or a placebo was given to women during the first 5 days after delivery. One spray per nostril, for a total of $3 \mathrm{U}$ of oxytocin was used before manual expression. Beginning on the $3^{\text {rd }}$ day, the quantity of milk produced in each session was recorded. The cumulative milk volume produced was 3-5 times higher in primiparous mothers and 2 times higher in multiparous mothers who used oxytocin as compared with those who used placebo. Milk composition was not influenced by the administration of oxytocin. In 2006 Fewtrell et al (63) conducted another double-blind RCT in which either oxytocin nasal spray $(100 \mu 1 /$ spray $)$ or a placebo was given to 27 and 24 mothers of preterm infants (GA $<35$ weeks), respectively. No statistically significant differences were found in milk composition and volumes produced.

An combination of oxytocin nasal spray and metoclopramide has been tested in an adoptive mother who achieved milk production by the $10^{\text {th }}$ day of the treatment (13).

Transfer to maternal milk: No studies have been reported.

Side effects for infant and for mother: No reports are available about side effects on infants. The above mentioned trials $(62,63)$ reported no side effects in mothers.

Recommended dosage for galactogogic effect: 1 spray per nostril $(40 \mathrm{U} / \mathrm{ml})$ before breast-pump $(62,63)$.

Recommendation for breastfeeding: There is no relevant information available due to the limited 
clinical experience in the use of oxytocin as galactagogue. Ruiz et al (62) considered oxytocin valid and reliable to promote milk production. A Cochrane review (61) considered oxytocin capable of increasing milk production and recommended its use as needed.

\section{Growth hormone (GH, Somatotropin)}

Mechanism of action: It is not yet completely well known (64).

Clinical data: The ability of $\mathrm{GH}$ to stimulate milk production has been well studied in animal models but few studies have been carried out on humans. Milsom and his co-workers carried out a double-blind RCT on 16 women $(65,66)$ who received recombinant $\mathrm{GH}(\mathrm{rhGH})$ at a dosage of $0.1 \mathrm{IU} / \mathrm{kg} /$ day or a placebo. After seven days of therapy, milk production increased from basal levels of $18.5 \pm 1.4 \%$ and $11.6 \pm 2 \%$ in treated group and control, respectively $(p<0.02)$. Milk composition and IGF-1 levels in milk remained the same in the two groups.

Gunn et al carried out a double-blind RCT on 20 mothers of preterm babies (GA 26-34 weeks) who had reduced milk production. Ten mothers received hGH (0.2 IU/kg/day sc for 7 days) and another 10 received placebo (67). Milk production in treated mothers increased from 139 $\pm 49 \mathrm{ml} /$ day to $175 \pm 46 \mathrm{ml} /$ day after 7 days of treatment (an increase of $31 \%, p<0.01$ ).

Transfer to breast milk: GH levels in milk do not increase after sc administration $(65,66)$. IGF1 levels in milk increases but the concentrations are 100 times lower than in plasma.

Side effects for infant and for mother: Not reported $(65,66)$.

Recommended dosages for galactogogic effect: $0.1-0.2 \mathrm{UI} / \mathrm{kg} /$ day $\mathrm{sc}$ for 7 days (65-67). According to a small 1998 study a dose of 0.2 $\mathrm{UI} / \mathrm{kg} /$ day is necessary in order to obtain a satisfactory galactogogic effect (68).

Recommendation for breastfeeding: There is no information due to limited clinical experience in the use of GH as a galactogogue (44).

\section{Thyrotrophin Releasing Hormone (TRH):}

Mechanism of action: TRH stimulates the secretion of TSH and PRL by the pituitary gland $(37,69-71)$.

Clinical data: Reports are conflicting. In a double-blind RCT, 8 women were treated with synthetic TRH $(20 \mathrm{mg}$ po, 3 times a day, 30 minutes before breastfeeding) and another 8 with placebo for 4 weeks after delivery. Treated women exhibited higher concentrations of serum PRL as well as a higher increment in response to suckling. Milk volume and composition remained the same in the two groups (71).

This was confirmed with another study carried out in full nursing women treated either oral TRH ( $5 \mathrm{mg}, 2$ times a day, for 4 weeks) or a placebo (70). On the other hand, in a group of women with lactational insufficiency receiving 5-20 mg TRH twice daily for 5 days, basal PRL concentrations markedly increased, breast engorgement and milk letdown increased and full nursing was restored. Ylikorkala et al (72) also observed no improvement in lactation.

Bose et al (73) examined the induction of lactation in 7 mothers (including an adoptive mother) between 10 and 150 days after delivery. All mothers produced milk; 3 completely breast-fed, and 2 provided at least half of the infants' needs. The adoptive mother and another mother produced a limited quantity of milk. Peters et al (74) also observed rise in prolactin levels and milk yield in some women in response to TRH therapy.

Transfer to breast milk: No data are available.

Side effects for infant and for mother: No side effect has been found in infants (71) Some cases of iatrogenic hyperthyroidism (70) and short episodes of diaphoresis (74) have been found in mothers. TRH administration increases the maternal levels of $\mathrm{T} 3$ and $\mathrm{T} 4$, and both hormones appear at low concentration in the mother's milk (37).

Recommended dosage for galactogogic effect: One spray per nostril $(1 \mathrm{mg}), 4$ times per day for 10 days (73). This drug can also be given intravenously $(200 \mu \mathrm{g})(74)$ or orally $5-20 \mathrm{mg}$ 2-3 times/day for a period ranging from 5 days to 4 weeks (69-72). 
Recommendation for breastfeeding: The currently available data are insufficient to consider TRH as a galactagogic drug of choice.

\section{Medroxyprogesterone}

Mechanism of action: It is unknown

Clinical data: Limited clinical studies suggest that the drug is moderately effective in increasing milk production $(34,75,29)$.

Transfer to maternal milk: Medroxyprogesterone passes through maternal milk, with an M/P ratio of 1:1 (76).

Side effects for infant and for mother: No side effects are reported in infants and mothers, other than amenorrhoea $(34,36,77)$.

Suggested doses for galactogogic effect: Due to the limited clinical experience in the use of medroxyprogesterone as a galactogogue, no welldefined studies relating to dosage have been reported. The reported dosage is an injection of $150 \mathrm{mg}(34,76)$.

Recommendation for breastfeeding: The AAP considers medroxyprogesterone compatible with breast feeding (36). Briggs et al hypothesized an incremental increase in milk production and in the duration of lactation using this drug during the postpartum period (37). However, the currently available data are insufficient to consider medroxyprogesterone as a galactogogue of choice.

\section{HERBS AND NATURAL SUBSTANCES}

The use of natural products believed to be able of increasing milk production has a long history. The most frequently used products include fenugreek, galega, and Mary's thistle. Anise, basil, fennel, mauve, verbena, cumin, grape, and coffee have also been traditionally used.

\section{Fenugreek (Trigonalla foenum graecum)}

Fenugreek is used in India and in some middleeastern countries as a spice and a medicine. It is believed to have a number of therapeutic uses, including anti-inflammatory, reconstituent and galactagogic effect. The side effects most commonly reported are a maple-like smell of the urine, breast milk, and perspiration, diarrhea, as well as the worsening of symptoms in individuals with asthma or hypoglycemia. The potential for transfer to milk or side effects in the infant are unknown. As is the case for most herbal products, the dose necessary to obtain a galactogogic effect has not been defined.

Only one study on the effect of fenugreek on lactation has been reported. Swafford asked 10 mothers to maintain a diary of the quantity of milk produced with a pump for a period of two weeks. In the first week, baseline milk production was evaluated; in the second week, mothers took fenugreek, 3 cups, three times daily. In the first week average quantities were $207 \mathrm{ml} /$ day, whereas, milk production in the second week averaged $464 \mathrm{ml} /$ day $(p=0.004)$. Unfortunately, the report excluded any information regarding the characteristics of the mothers enrolled in the study or the postpartum period during which the study was done. Nevertheless, the daily milk quantities reported during treatment do not seem to be particularly high (78).

\section{Galega (Goat's rue, Galega officinalis)}

This herb has been widely used since the beginning of 1900, when it was discovered to increase milk production in cows. Galega has been shown to cause hypoglycemia. No recommended dose and no side effects are reported in the mother. Transfer in maternal milk is unknown (79). However, in the infants of mothers taking a blend of liquorices, fennel, anise and galega, side effects that include sleepiness, hypotonia, lethargy, vomiting, and scarce suction have been reported. All these symptoms regress with the interruption of breast feeding (80).

\section{Silymarin (Milk thistle, Silybum marianum)}

While its major application has been to act as a liver protector (81), in recent years silymarin has been reported to have a galactogogic effect $(82,83)$. The active compound in milk thistle, derived from dried seeds, is silymarin. Silymarin comprises four flavolignans: silybin $(60-70 \%)$, silychristin (20\%), silydianin (10\%) and isosilybin (5\%) (81). Silybin in the most active component of the mixture and is available in poison centers as an injectable medication for the treatment of food poisoning by Amanita phalloides.

The flavolignans are bioflavonoid phytoestrogens. They posses a steroid-like structure which might explain their ability to protect the liver by stimulating protein synthesis. It is also possible that they could act on estrogen receptors (ER2) by limiting the endogenous receptors antagonism of milk production $(81,82)$. In addition to the data on the galactogogic activity of milk thistle in cows (76), a single human is 
also available (82). The authors who stated that the product was not transferred to maternal milk administered, to 25 women, $420 \mathrm{mg}$ orally of micronized silymarin and to another 25 placebo for 63 days. They evaluated the quantity of milk produced on days 0,30 , and 63 , and they collected milk samples for a qualitative profile. The authors reported an increase in daily milk production equal to $86 \%$ in the treated group, versus $32 \%$ in the placebo group. A significant limitation of this study was the lack of detailed information regarding the characteristics of mothers and infants under test. The average age of infants at enlistment time was 4.5-5.2 months. The study was neither randomized nor doubleblinded.

\section{DISCUSSION AND CONCLUSIONS}

It is imperative to use galactagogues only when reduced milk production from treatable causes have been excluded and educational plans failed. Pharmacotherapy should only be recommended for mothers who desires to breast-feed but are unable to maintain an appropriate lactation. For the choice of the appropriate galactogogue is important to evaluate the potential benefit and side effects, both for the mother and the infant. In Table 5, indications about dosage, length of treatment, side effects for the mother and the infant are reported for some galactogogues.
Galactogogic effect has been reported for many substances even if there are few well conducted scientific studies. In particular herbal medications are exempt from rigorous evaluations and standardization (79). Few scientific studies have been conducted to evaluate the effectiveness and side effects of these herbs. We do not recommend these herbs as the first choice treatments.

For hormonal therapy, scientific studies are not generally well conducted and too few in number. The applied dosages as well as routes of administration are inconsistent. In addition, due to the potential for serious adverse effects we do not recommend them for clinical practice.

We consider Domperidone the drug of first choice as galagtogogue because of its proven efficacy, lack of side effects in infants and rare side effects in mothers.

Where domperidone is not available for clinical use (i.e. in the USA), metoclopramide can be used to obtain a galactagocic effect.

With regard to antipsycothic drugs, they have the tendency to concentrate in the brain and cause potential short and long-term effects in the development of the CNS of the infant.

\section{FUTURE PROSPECTS}

More randomized controlled studies are needed for all galactogogues, in particular for herbal/natural substances to establish efficacy, standard dosages and safety.

Table 5. Dosage information for selected galactogogues

\begin{tabular}{|c|c|c|c|c|c|}
\hline & Dosage & $\begin{array}{l}\text { Length of } \\
\text { therapy }\end{array}$ & Side effects in mother & $\begin{array}{l}\text { Side effects in } \\
\text { infant }\end{array}$ & Recommended \\
\hline Domperidone* & $\begin{array}{l}10 \mathrm{mg} \mathrm{po} \\
3 \text { times/die }\end{array}$ & 1-2 weeks & $\begin{array}{l}\text { Oral mucosal dryness, skin } \\
\text { eruption, itch, headache, and } \\
\text { gastrointestinal disorders, } \\
\text { dystonia, cardiac arrhythmia, } \\
\text { sudden death }\end{array}$ & Not reported & +++ \\
\hline Metoclopramide & $\begin{array}{l}10-15 \mathrm{mg} \text { po } \\
3 \text { times/day }\end{array}$ & 1-4 weeks & $\begin{array}{l}\text { Headache, anxiety intestinal } \\
\text { disorders, } \\
\text { sleepiness, nervousness, } \\
\text { extrapyramidal manifestation }\end{array}$ & $\begin{array}{l}\text { Mild and transient } \\
\text { intestinal discomfort }\end{array}$ & ++ \\
\hline Chlorpromazine & $\begin{array}{l}25 \mathrm{mg} \text { po } \\
3 \text { times a day }\end{array}$ & 1 week & $\begin{array}{l}\text { Extrapyramidal symptoms and } \\
\text { weight increase }\end{array}$ & $\begin{array}{l}\text { Lethargy, sleepiness, } \\
\text { reduced behavioral } \\
\text { performance }\end{array}$ & - \\
\hline Sulpiride* & $\begin{array}{l}50 \text { mg po } \\
2-3 \text { times a } \\
\text { day }\end{array}$ & 1-4 weeks & $\begin{array}{l}\text { Headache, fatigue, potential } \\
\text { extrapyramidal symptoms, acute } \\
\text { dystonic reactions, and } \\
\text { endocrine dysfunction }\end{array}$ & Not reported & - \\
\hline
\end{tabular}

* not available in the United States 


\section{REFERENCES}

1. Breastfeeding and the use of human milk. American Academy of Pediatrics.Work group on Breastfeeding. Pediatrics. 1997;100(6):1035-1039.

2. Canadian Paediatric Society Clinical Practice Guidelines Nutrition for healthy term infants: A joint statement of the Canadian Pediatric Society, dietitians of Canada and health Canada. Paediatr Child Health. 1998;3 (2):109-116

3. Chatterton RT, Hill PD, Aldag JC, Belknap SM, Jinman MJ. Relation of plasma oxytocin and PRL concentrations to milk production in mothers of preterm infants: influence of stress. J Clin Endocrinol Metab. 2000; 85(10):3661-3668.

4. Ehrenkranz RA, Ackerman BA. Metoclopramide effect on faltering milk production by mothers of premature infants. Pediatrics. 1986;78:614-620.

5. Sjölin S, Hofvander Y, Hillervik C. Factors related to early termination of breast feeding. A retrospective study in Sweden. Acta Paediatr Scand. 1977;66(4):505-511.

6. Brogden RN, Carmine AA, Heel RC, Speight TM, Avery GS. Domperidone. A review of its pharmacological activity, pharmacokinetics and therapeutic efficacy in the symptomatic treatment of chronic dyspepsia and as an antiemetic. Drugs. 1982;24(5):360-400.

7. Cox DB, Owens RA, Hartmann PE. Blood and milk prolactin and the rate of milk syntesis in women. Exp Phisiol. 1996; 81: 1007-20

8. Zuppa AA, Tornesello A, Papacci P, Tortorolo G, Segni G, Lafuenti G, Moneta E, Diodato A, Sorcini M, Carta S. Relationship between maternal parity, basal prolactin levels and neonatal breast milk intake. Biol neonate 1988; 53:144-7.

9. Campbell-Yeo ML, Allen AC, Joseph KS, Ledwidge JM, Allen VM, Dooley KC. Study protocol: a double blind placebo controlled trial examining the effect of domperidone on the composition of breast milk. BMC Pregnancy and Childbirth. 2006; 6:17.

10. De Gezelle H, Ooghe W, Thiery M, Dhont M. Metoclopramide and breast milk. Eur J Obstet Gynecol Reprod Biol. 1983;15(1):31-36.

11. Biervliet FP, Maguiness SD, Hay DM, Killick SR, Atkin SL. Induction of lactation in the intended mother of a surrogate pregnancy: Case report. Hum Reprod. 2001;16:581-583.

12. Brogden RN, Carmine AA, Heel RC, Speight TM, Avery GS. Domperidone. A review of its pharmacological activity, pharmacokinetics and therapeutic efficacy in the symptomatic treatment of chronic dyspepsia and as an antiemetic. Drugs. 1982;24(5):360-400.

13. Cheales-Siebenaler NJ. Induced lactation in an adoptive mother. J Hum Lact. 1999;15:41-43.

14. Ertl T, Sulyok E, Ezer E, Sárkány I, Thurzó V, Csaba IF. The influence of metoclopramide on the composition of human breast milk. Acta Paediatr Hung. 1991;31:415-422.
15. Gupta AP, Gupta PK. Metoclopramide as a lactogogue. Clin Pediatr (Phila). 1985;24:269-272.

16. Guzmán V, Toscano G, Canales ES, Zárate A. Improvement of defective lactation by using oral metoclopramide. Acta Obstet Gynecol Scand. 1979;58:53-55.

17. Harrington RA, Hamilton CW, Brogden RN, Linkewich JA, Romankiewicz JA, Heel RC. Metoclopramide. An updated review of its pharmacological properties and clinical use. Drugs. 1983;25:451-494.

18. Kauppila A, Anunti P, Kivinen S, Koivisto M, Ruokonen A. Metoclopramide and breast feeding: efficacy and anterior pituitary responses of the mother and the child. Eur J Obstet Gynecol Reprod Biol. 1985;19:19-22.

19. Kauppila A, Arvela P, Koivisto M, Kivinen S, Ylikorkala O, Pelkonen O. Metoclopramide and breast feeding: transfer into milk and the newborn. Eur J Clin Pharmacol. 1983;25:819-823.

20. Kauppila A, Kivinen S, Ylikorkala O. A dose response relation between improved lactation and metoclopramide. Lancet. 1981;1(8231):11751177.

21. Kauppila A, Kivinen S, Ylikorkala O. Metoclopramide increases PRL release and milk secretion in puerperium without stimulating the secretion of thyrotropin and thyroid hormones. J Clin Endocrinol Metab. 1981;52:436-439.

22. Sousa PLR. Metoclopramide and Breast-feeding. Br Med J. 1975;1:512.

23. Toppare MF, Laleli Y, Senses DA, Kitaper F, Kaya IS, Dilmen U. Metoclopramide for breast milk production. Nutrition Res. 1994;14:10191029

24. Lewis PJ, Devenish C, Kahn C. Controlled trial of metoclopramide in the initiation of breast feeding. Br J Clin Pharmacol. 1980;9:217-219.

25. Hansen WF, McAndrew S, Harris K, Zimmerman MB. Metoclopramide effect on breastfeeding the preterm infant: a randomized trial. Obstet Gynecol. 2005;105(2):383-389.

26. Sankaran K, Yeboah E, Bingham WT, Ninan A. Use of metoclopramide in preterm infants. Dev Pharmacol Ther. 1982;5:114-119.

27. Hallbauer U. Sulpiride (Egonyl)- use to stimulate lactation. S Afr Med J. 1997;87:774-775.

28. Hampton T. FDA warns against breast milk drug. JAMA. 2004;292:322.

29. Hannon PR, Duggan AK, Serwint JR, Vogelhut JW, Witter F, De Angelis C. The influence of medroxyprogesterone on the duration of breastfeeding in mothers in an urban community. Arch Pediatr Adolesc Med. 1997;15, 151:490-496.

30. Heykants J, Hendriks R, Meuldermans W, Michiels M, Scheygrond H, Reyntjens H. On the pharmacokinetics of domperidone in animals and man. IV. The pharmacokinetics of intravenous domperidone and its bioavailability in man following intramuscular, oral and rectal administration. Eur J Drug Metab Pharmacokinet. 1981;6:61-70. 
31. Hofmeyer GJ, Van Iddekinge. Domperidone and lactation. Lancet.1983;1:647.

32. Hofmeyer GJ, Van Iddekinge B, Blott JA. Domperidone: secretion in breast milk and effect on puerperal PRL levels. Br J Obstet Gynaecol. 1985;92(2):141-144.

33. Joss RA, Goldhirsch A, Brunner KW, Galeazzi RL. Sudden death in cancer patient on high-dose domperidone. Lancet. 1982;1:1019.

34. Karim M, Ammar R, El Mahgoub S, Ganzoury B, Fikri F, Abdou Z. Injected proesterone and lactation. Br Med J. 1971;1:200-203.

35. Lewis JH, Weingold AB. The use of gastrointestinal drugs during pregnancy and lactation. Am J Gastroenterol. 1985;80:912-923.

36. American Academy of Pediatrics Committee on Drugs. The transfer of drugs and other chemicals into human breast milk. Pediatrics. 2001;108:776789.

37. Briggs GG, Freeman RK, Yaffe SJ, eds. Drugs in pregnancy and lactation: A reference guide to fetal and neonatal risk with access code. New York: Lippincott Williams\& Wilkins; 2006.

38. Delaloye J-F, De Grandi P, Vial Y, Hohlfeld P. Médicaments grossesse et lactation. Médecine \& Hygiène, Département livre Georg 46, Chemin de la Mousse, 1225 Chêne-Bourg (Souisse). 1997.

39. Barone JA. Domperidone: a peripherally acting dopamine2-receptor antagonist. Ann Pharmacother. 1999;33:429-440.

40. Da Silva OP, Knoppert DC, Angelini MM, Forret PA. Effect of domperidone on milk production in mothers of premature newborns: a randomized, double-blind, placebo-controlled trial. CMAJ. 2001;164:17-21.

41. Petraglia F, De Leo V, Sardelli S, Pieroni ML, D'Antona N, Genazzani AR. Domperidone in defective and insufficient lactation. Eur J Obstet Gynecol Reprod Biol. 1985;19:281-287.

42. FDA cautions breast-feeding moms. FDA Consum. 2004;38:6.

43. Da Silva OP, Knoppert DC. Domperidone for lactating women. CMAJ. 2004 28;171:725-726.

44. Gabay MP, Pharm D, BCPS. Galactogogues: Medications that induce lactation. J Hum Lact. 2002;18:274-279.

45. Bryant CA. Nursing the adopted infant. J Am Board Fam Med. 2006;19:374-379.

46. Giaccone G, Bertetto O, Calciati A. Two sudden deaths during prophylactic antiemetic treatment with high doses of domperidone and methylprednisolone. Lancet.1984;2:1336-1337.

47. Osborne RJ, Slevin ML, Hunter RW, Hamer J. Cardiotoxicity of intravenous domperidone. Lancet. 1985;2:385.

48. Roussak JB, Carey P, Parry H. Cardiac arrest after treatment with intravenous domperidone. $\mathrm{Br}$ Med J. 1984;289:1579.

49. Weichert CE. Lactational reflex recovery in breast-feeding failure. Pediatrics. 1979;63:799803.
50. Blacker KH, Weinstein BJ, Ellman GL. Mothers milk and chlorpromazine. Am J Psychol. 1962;114:178-179.

51. Wiles DH, Orr MW, Kolakovska T. Chlorpromazine levels in plasma and milk of nursing mothers. Pr J Clin Pharmacol. 1978;5:272273.

52. Yoshida K, Smith B, Craggs M, Kumar R. Neuroepileptic drugs in breast-milk: a study of pharmacokinetics and of possible adverse effects in breast-fed infants. Psychol Med. 1998;28:81-91.

53. Gentile S. Infant safety with antipsychotic therapy in breast-feeding:a systematic review. J Clin Psychiatry. 2008;69:666-673.

54. Aono T, Shoioji T, Aki T, Hirota K, Nomura A, Kurachi K. Augmentation of puerperal lactation by oral administration of sulpiride. J Clin Endocrinol Metab. 1979;48:478-82.

55. Mancini AM, Guitelman A, Vargas CA, Debeljuk L and Aparicio NJ. Effect of sulpiride on serum PRL levels in humans. Clin Endocrinol Metab. 1976;42:181-184.

56. Ylikorkala O, Kauppila A, Kivinen S, Viinikka L. Sulpiride improve inadeguate lactation. Br Med J (Clin Res Ed). 1982;285:249-251.

57. Polatti F. Sulpiride isomers and milk secretion in puerperium. Clin Exp Obstet Gynecol. 1982;9:144-147.

58. Aono $\mathrm{T}$, Aki $\mathrm{T}$, Koike $\mathrm{K}$, Kurachi K. Effect of Sulpiride on poor puerperal lactation. Am J Obstet Gynecol. 1982;143:927-932.

59. Ylikorkala O, Kauppila A, Kivinen S, Viinikka L. Treatment of inadequate lactation with oral sulpiride and buccal oxytocin. Obstet Gynecol. 1984;63:57-60.

60. Bazire S. Psychotropic Drug Directory. Salisbury, UK: Fivepin Publishing, 2003/04: 209-216.

61. Renfrew MJ, Lang S, Woolridge M. Oxytocin for promoting successful lactation. Cochrane Database Syst Rev. 2000;(2):CD000156. Review.

62. Ruis H, Rolland R, Doesburg W, Broeders G, Corbey R. Oxytocin enhances onset of lactation among mothers delivering prematurely.Br Med J (Clin Res Ed). 1981;283:340-342.

63. Fewtrell MS, Loh KL, Blake A, Ridout DA, Hawdon J. Randomised, double blind trial of oxytocin nasal spray in mothers expressing breast milk for preterm infants. Arch Dis Child Fetal Neonatal Ed. 2006;91:169-174.

64. Trott JF, Vonderhaar BK, Hovey RC. Historical perspectives of PRL and growth hormone as mammogens, lactogens and galactagogues-agog for the future! J Mammary Gland Biol Neoplasia. 2008;13:3-11.

65. Breier BH, Milsom SR, Blum WF, Schwander J, Gallaher BW, Gluckman PD. Insulin-like growth factors and their binding proteins in plasma and milk after growth hormone-stimulated galactopoiesis in normally lactating women. Acta Endocrinol (Copenh). 1993;129:427-435.

66. Milsom SR, Breier BH, Gallaher BW, Cox VA, Gunn AJ, Gluckman PD. Growth hormone 
stimulates galactopoiesis in healthy lactating women. Acta Endocrinol (Copenh). 1992;127:337-343.

67. Gunn AJ, Gunn TR, Rabone DL, Breier BH, Blum WF, Gluckman PD. Growth hormone increases breast milk volumes in mothers of preterm infants. Pediatrics. 1996;98:279-282.

68. Milsom SR, Rabone DL, Gunn AJ, Gluckman PD. Potential role for growth hormone in human lactation insufficiency. Horm Res. 1998;50:147150.

69. Kivinen S, Kauppila A, Ylikorkala O, Puukka M. Effect of oral thyrotrophin releasing hormone on serum PRL, thyrotropin and total thyroxine levels in postpartum women. Z Geburtshilfe Perinatol. 1978 Apr;182:113-116.

70. Tyson JE, Perez A, Zanartu J. Human lactational response to oral thyrotropin releasing hormone. $\mathrm{J}$ Clin Endocrinol Metab. 1976;43:760-776.

71. Zarate A, Villalobos H, Canales ES, Soria L, Arcovedo F, MacGregor C. The effect of oral administration of thyrotropin-releasing hormone on lactation. J Clin Endocrinol Metab. 1976;43:301-305.

72. Ylikorkala O, Kivinen S., Kauppila A. Oral administration of TRH in puerperal women: effect on insufficient lactation, thyroid hormones and on the responses of TSH and PRL to intravenous TRH. Acta Endocrinol (Copenh). 1980;93(4):413418

73. Bose CL, D'Ercole J, Lester AG, Hunter RS, Barret JR. Relactation by mothers of sick or premature infants. Pediatrics. 1981;67:565-569.

74. Peters F, Schulze-Tollert J, Schuth W. Thyrotrophin-releasing hormone: a lactationpromoting agent? $\mathrm{Br} \mathrm{J}$ Obstet Gynaecol. 1991;98:880-885.

75. Guiloff E, Ibarra-Polo A, Zanartu J, Toscanini C, Mischler TW, Gomez-Rogers C. Effects of contraception on lactation. Am J Obstet Gynecol. 1974;118:42-45.
76. Saxena BN, Shrimanker K, Grudzinskas JG. Levels of contraceptive steroids in breast milk and plasma of lactating women. Contraception. 1977 Dec;16(6):605-613.

77. Kelsey JJ. Hormonal contraception and lactation. J Hum Lact. 1996;12:315-318.

78. Swafford S, Berens P. Effect of fenugreek on breast milk production. Abstract 5th International Meeting of the Academy of Breastfeeding Medicine September 11-13, 2000, Tucson, Ariz Academy of Breastfeeding Medicine News and Views 2000;6(3).

79. Caroline J, Chantry MD. The academy of breastfeeding medicine protocol committee. Protocol $\mathrm{n}^{\circ}$ : Use of galactogogues in initiating or augmenting maternal milk supply. 2004.

80. Rosti L, Nardini A, Bettinelli ME, Rosti D. Toxic effect of an herbal tea mixture in two newborns. Acta Pediatr.1994;83:683

81. Pradhan SC, Girish C. Hepatoprotective herbal drug, silymarin from experimental pharmacology to clinical medicine. Indian $\mathrm{J}$ Med Res. 2006; 124:491-504.

82. Carotenuto D, Di Pierro F. Studio sulla tollerabilità ed efficaciadella silimarina BIO-C $\mathbb{R}$ (Piùlatte $\AA$ ) micronizzata come galattagogo. Acta Neonatologica \& Pediatrica. 2005;4:393-40.

83. Vojtisek B. Milk Thistel (silybum marianum) in the feed of ketotik cow. Veterinary Medicine. 1991.

84. Kren V, Walterova D. Silybin and Silymarin new effects and applications. Biomed. Papers. 2005;149:29-41.

85. Gallo D, Giacomelli S, Ferlini C, Raspaglio G, Apollonio P, Prislei S, Riva A, Morazzoni P, Bombardelli E, Scambia G. Antitumor activity of the silybin- phosphatidylcholine complex, IdB 1016, against human ovarian cancer. Eur J Cancer. 2003;39:2403-2410. 